\title{
The obstacles of China's economic transformation
}

\author{
ZHOU Yu-feng ${ }^{1,2}$ \\ (1. Department of Management, Chongqing Medical University, Chongqing 400016, China; \\ 2. Medicine and Social Development Research Center, Chongqing Medical University, Chongqing 400016, China)
}

\begin{abstract}
In the past 30 years, China has gone from the transformation from a planned economy to a market economy, from the extensive economic growth mode to intensive economic growth model, and from relying on investment and export-led economy to relying on domestic demand and stimulating economic. China's economic transformation includes three parts: The first is the reform of economic system, the second is the change in the pattern of economic growth and the third is the adjustment of economic structure. This article describes the historical evolution and the reality of China's economic transformation, analysis the obstacles to China's economic transformation, and on this basis, put forward some suggestions.
\end{abstract}

Key words: obstacles; China; economic transformation

\section{The historical evolution and the reality of China's economic transformation}

In the past six decades, China has experienced two major economic transformations. One is a transition from the new democratic economy to a socialist planned economy, the other is transition from a socialist planned economy to a socialist market economy.

After The Third Plenum of the Eleventh Centeral Committee in 1978, China started an all-round reform and opening up, and China's economic system has begun to move gradually from the socialist planned economy to a socialist market economy.

In 1979, DENG Xiao-ping met with American visitors, and they discussed the topic-The socialist system can also have a market economy. At that time, the concepts of commodity economy and market economy are still restricted. In 1981, China confirmed the existence of commodity production and commodity exchange, but didn't mention the concept of commodity economy. In 1982, China government said clearly put forward the view that plan as a tool is the main body and market as a tool is complementary. But the concept of commodity economy is still difficult to be put forward then. Until 1984, for the first time, China said that the socialist economy is the planned commodity economy based on the socialist public ownership. DENG Xiao-ping expressed this point of view with new words which our ancestors have not said, and wrote a new version of political economy. In 1987, China has clearly put forward the model of economic adjustment mechanism, which is the state controls market and market leads enterprises. In 1992, DENG Xiao-ping inspected the south and delivered an important speech. He said: "A little more plan or a little more market is not the essential difference between socialism and capitalism”. Just in this year, China has clearly stated that the goal of China's economic reform is to establish a socialist market economic system.

ZHOU Yu-feng, associate professor, Department of Management, Medicine and Social Development Research Center, Chongqing Medical University; research fields: economic theory and practice. 
After 30 years of reform and opening up, the building of China's socialist market economy has made remarkable results: Market has played a fundamental role in the allocation of some important resources, such as price, supply and demand, competition, and so the market mechanism has taken shape; The primary stage of socialism basic economic system has been established; The legal status of non-public economy is confirmed; The common development of multi-ownership economy has basically showed the prototype; The social security system has been gradually established and further improved; The legal system of socialist market economy has begun to shape; Government organs have been streamlined for many times and great changes have taken place in government functions.

In fact, China's economic transformation not only refers to the economic reform from planned economy to market economy, but also refers to the change in the pattern of economic growth and the adjustment of economic structure. If China stimulate economic over-relianced on investment, and it will inevitably cause the contradiction of overproduction and inefficient demand. So, although Chinese government have paid a lot of effort on China's economic transformation, the results are not good enough.

\section{The main obstacles to China's economic transformation}

\subsection{The long-term imbalances of the economic structure}

During 30 years' reform and opening up, China's economic structure has been in unbalanced state for a long period. Specific performance is that from the internal point of view, mainly imbalances are between investment and consumption; And from an external point of view, primarily in international trade and balance of payments surplus, foreign exchange increased significantly. Overall, China's economy over the last three decades of growth has being depended on investment and exports, consumption is relatively very less. In 1995, China had put forward to achieve the fundamental transformation of economic growth. By 2005, China has formulated the "Eleventh Five-Year Plan", and put forward that the focus work of the next five years is to realize the transformation of economic growth mode. In 2007, China stressed the three changes of economic development model: from mainly relying on investment and exports change to relying on the coordinated development of consumption, investment and exports; From mainly relying on manufacturing industry change to relying on the coordinated development of the primary industry, manufacturing industry and tertiary industry; From mainly relying on resource consumption change to relying on the coordinated development of technological advances, improved quality of workers and management innovation. In 2008, the subprime mortgage crisis erupted in the United States. The crisis has brought inevitable impact to China's economic, and China also found that there still are some problems existing in its own economic structure. China's economy in the past over-reliance on exports and investment, exports are greatly affected by the crisis.

In 1952, China's private consumption accounts are 69\% of GDP, and the United States is the same level now. But at that time, China's productions almost revolve around food, clothing and shelter, so it is understandable that the ratio was very high. Anyhow, in the past 60 years, private consumption accounts for a share of GDP have plummeted, while the proportion of government expenditure in GDP was rising in a straight line.

\subsection{The legacy of economic reform}

In 1992, China put forward the direction of economic reform in order to establish and perfect the socialist market economic system. The most basic requirement of market economy is that markets must play a fundamental 
role in the allocation of resources, and resource prices should be determined largely by market supply and demand. However, in fact, China governments still hold the power of some important resource allocation. The government authorities have been under the influence of utilitarian thinking for a long time, and hold the power of important resources allocation. In fact, these important resources are not configured by the market, but by the government authorities in accordance with their wills.

Since the reform and opening up, China has put forward the national policy that economic construction is the center. Therefore, many government agencies think that since economic construction is the center, and GDP should mainly be used to measure the political achievement. Under the pressure of the performance evaluation, some local governments began to set up enterprises, attract investment and construction project regardless of the actual. In order to obtain the growth of GDP, these local governments have not thought of other factors such as education, culture, health and environment. In addition, local governments have to carry out large-scale material production, or will not be able to maintain the balance of budgetary revenues and expenditures.

\subsection{The psychological factors of the government and people}

The Government's self-positioning in the market economy is not accurate, and some local governments serve as the main body of the market economy naturally. Some government officials believe that they are the protagonist of the major decision-making and investment. Many government officials habitually think that their main achievement is to manage business and specific economic work well. These government officials did not realize the important view that the government's main duties in a market economy system are social services and macro-control. The government should provide good service to people in education, health, housing, social security, etc. Such people could have plenty of consumer confidence, and the development of China's economy may have sustainability. This is a key component of China's economic transformation.

The major reason why 30 years of China's reform has made great achievements is that Chinese people have the spirit of exploration and practice. But people's psychology is in favor of economic transformation, it also impedes economic transformation. After the reform and opening, the material desires which have been repressed for a long time are aroused. Under the strong impact of commodity economy, the primacy of money is beginning to penetrate all sectors of Chinese society. At the same time, a strong desire to get rich has led to a wide range of short-term pursuit of material interests. In addition, due to the intrinsic psychological precipitation, people are instinctively rejection to reform and innovation. The hidebound thought and behavior of people hinder economic transformation.

\section{Several measures to overcome the obstacles}

\subsection{To promote industrial upgrading actively}

Before the sub-prime mortgage crisis, from China's economic structure, investment is the first one to economic contribution, export is the second and consumption is the third. After the sub-prime crisis, exports suffered a heavy blow, but investment remains the primary forces, consumer rank second, with exports retreated to third. In the process of improving domestic demand, increase in consumer demand is particularly important. China's domestic demand, especially consumer demand, experienced years of development and adjustment, has undergone great changes. The expansion of domestic demand, especially the expansion of domestic consumption, has brought a very large opportunity to industrial upgrading. And industrial upgrade has been in the core of 
economic transformation.

There are three levels in industrial upgrading: The first level of the whole national economy is in the industry structure adjustment, the key is to make the third industry gradually occupy a relatively important position; The second level is the second intra-industry structural adjustment; The third level is the same with the industry restructuring, which is enterprise upgrade.

The government should actively provide conditions for industrial upgrading: First to mobilize and protect the enterprise innovation. To accomplish this, government must protect corporate intellectual property, trademarks, patents as well as the establishment of a sound standard market order. They should build a shared technology platform and create a good system environment. In the good environment, the enterprises are willing to restructure, upgrade and innovate.

\subsection{To accelerate the reform and innovation of system}

China really needs to achieve the economic transformation of economic growth pattern. This change will affect the existing pattern of interests, and inevitably encounter obstacles and resistance. To remove these obstacles and resistance, on the one hand, we must let the price mechanism play a fundamental role in resource allocation; On the other hand, economic growth can not rely on exports to support permanently. Therefore, the key to China's economic transformation is to push forward market-oriented reforms unswervingly.

Although the general direction of reform is to establish and perfect the socialist market economic system, however, in this process, there would be many unexpected profound social contradictions. Many current social disharmonious are caused by these contradictions. In the process of economic transformation, the country's economic system and socialist market economic system have many imperfections. How to maintain social stability and harmony is significant issues that reform and innovation must take into account.

\subsection{To realize the transformation of government functions}

In the process of the establishment and improvement of market economic system, the government must promote the building of market economy system, withdrawing from the field which should be regulated by the market itself, and the government also should monitor the market order. In this process, the government's role will be increasingly smaller, and the role of market will be growing larger. In the socialist market economy, the government is to serve the community, and must always put the social services as the government's top priority. The government should no longer be the main body of the allocation of resources, but the most important means of accessing to resources is the market and not the government. The government's main function is to maintain a normal market order, rather than being responsible for the development of production.

If the government functions are without fundamental changes, the problem of insufficient domestic demand can not be fully resolved too. This change has not resolved by administrative means, but realized by the market mechanism. The government must pay attention to the structural problems of investment and consumption, combine the expansion of domestic demand and economic growth, combine the expansion of domestic demand and the development of social undertakings, combine the expansion of domestic demand and improvement of people's livelihood. China's current focus of the financial payment is medical, education, low-cost housing, environmental protection and other public undertakings.

\subsection{To increase the consumer demand of residents}

The final obstacle of China's economic transformation is still inadequate, and the residents' consumption demand is the fundamental problem of economic transformation. In the process of China's economic system 
reform, because of some uncertain factors, consumer demand is not proportional to the growth of income, always at a low state. In the planned economy era, the state packages down all the social security such as medical, housing and education. But in a market economy era, the resident individual and unit will be responsible for the social security, which weakened other aspects of consumer desire. Some market-oriented initiatives of the state in education, health care, housing reform, making expenses in these three areas greatly increased. Education, medical care, housing problem is called the new "three big mountains". Although with China's economic growth, the income level of resident has greatly increased, but as long as the uncertainty of social security is not eliminated, consumer demand will not appear sharply increased.

\section{References:}

Chow, G. C.. (2007). China's economic transformation (2nd ed.). Edinburgh: Blackwell Publishing Limited.

HE, D. X. \& YAO, Z. Q.. (2008). Modern services and China's economic transformation. Retrieved Nevember 19, 2008, from http://www.cbmedia.cn/html/33/n-1933.html.

Garnaut, R. \& SONG, L. G. (2004). China's third economic transformation: The rise of the private economy. New Delhi: Routledge. WANG, M. K.. (2000). China's economic transformation over 20 years (English version). Beijing: Foreign Languages Press.

(Edited by Ruby and Linda)

(continued from Page 28)

Republic of Angola. (2004). Estratégia de Combate à Pobreza: Reinserção Social, Reabilitação e Reconstrução e Estabilização Económica. Ministério do Planeamento, Direç̧ão de Estudos e Planeamento.

Republic of Liberia. (1988). Liberia demographic and health survey 1986. (Bureau of Statistics, Ministry of Planning and Economic Affairs Monrovia, Liberia, Institute for Resource Development/Westinghouse Columbia, Maryland, U.S.A.)

Trostle, R..(2008). Global agricultural supply and demand: Factors contributing to the recent increase in food commodity prices. United States Department of Agriculture: Economic Research Service.

Uganda Bureau of Statistics (UBOS) \& Macro International Inc. (2007). Uganda demographic and health survey 2006. Calverton, Maryland, USA: UBOS and Macro International Inc.

United Nations Development Program. (1994). Human development report 1994. New York: Oxford University Press.

United Nations Development Program. (2004). Security with a human face: challenges and responsibilities. In: Afghanistan national human development report 2004. Islamic Republic of Afghanistan. UNDP Afghanistan.

United Nations. (2005). 2005 world summit outcome: Resolution adopted by the General Assembly (16th ed.). UN General Assembly. Weiser, S. D., et al.. (2007). Food insufficiency is associated with highrisk sexual behavior among women in Botswana and Swaziland. PLoS Med 4(10): e260. Doi:10.1371/journal. Pmed.0040260.

World Health Organization. (2008). World health report 2008: Primary health care, now more than ever. Switzerland World Health Organization. (2008). The global burden of disease updates 2004. Switzerland.

(Edited by Ruby and Chris) 